\title{
BORGES Y RULFO: OTRO DIÁLOGO POSIBLE
}

\section{BORGES AND RULFO: ANOTHER POSSIBLE DIALOGUE}

\author{
Rafael Olea Franco \\ El Colegio de México \\ rolea@colmex.mx
}

\begin{abstract}
Resumen: El primer grupo mexicano de lectores de la obra de Jorge Luis Borges surgió a inicios de la década de 1940 en Guadalajara; entre sus miembros estaban Juan José Arreola y Juan Rulfo, en cuya obra narrativa pueden encontrarse huellas del escritor argentino. A partir de la familiaridad de Rulfo con la obra inicial de Borges, este trabajo propone que existe una relación intertextual directa entre los relatos "Hombre de la esquina rosada", de Borges, y "La Cuesta de las Comadres", de Rulfo, incluyendo el modo narrativo de ambos textos, fundado en la construcción de una oralidad específica. Asimismo, se estudia el breve prólogo que el argentino dedicó a Pedro Páramo, novela por la cual Borges expresó una admiración permanente.
\end{abstract}

Palabras clave: Borges; Rulfo; "Hombre de la esquina rosada"; "La

Cuesta de las Comadres"; intertextualidad.

Abstract: The first group of Mexicans to read Jorge Luis Borges's work appeared at the beginning of the 1940's in Guadalajara; among its members were Juan José Arreola and Juan Rulfo, whose narrative work presents traces of the Argentinian writer. Arguing the familiarity of Rulfo with the initial work of Borges, this paper proposes that there is a direct intertextual relationship between the short stories "Hombre de la esquina rosada", by Borges, and "La Cuesta de las Comadres", by Rulfo, one which links the narrative style of the two texts to the construction of a specific orality. Reference is also made to the brief prologue that the Argentinian wrote for Pedro Páramo, a novel for which Borges expressed unfailing admiration.

Keywords: Borges; Rulfo; "Hombre de la esquina rosada"; "La Cuesta de las Comadres"; intertextuality.

Recepción: 6 de febrero de 2017; aceptación: 22 de mayo de 2017. 
Los dos mayores narradores de la literatura hispanoamericana; ambos de obras extremadamente condensadas, las más despojadas, antibarrocas por excelencia; el uno de origen y formación cultural europeos, que escribía en Buenos Aires o en la Biblioteca de Babel; el otro, de raigambre mestiza, que escribía en México con la entonación oral y coloquial de la gente del campo traspuesta a una escritura de asombroso refinamiento...

Augusto Roa Bastos, "La lección de Borges"

\section{InTROducción: Borges en MÉXico}

En 1964, la Revista Mexicana de Literatura difundió un número especial titulado "Homenaje a Borges". Además de los dos poemas ingleses del escritor argentino, trasladados al español por José Emilio Pacheco, esta edición incluyó una entrevista de Keith Botsford al autor (traducida por Carlos Monsiváis), así como tres ensayos analíticos, elaborados por Ramón Xirau, Emir Rodríguez Monegal y Juan García Ponce. Bajo el significativo título de “¿Quién es Borges?”, García Ponce se planteaba así el enigma en el que se debatía entonces la lectura de la obra de Jorge Luis Borges (1889-1986):

...abundan los que se empeñan en negarle precisamente todo rasgo personal, concreto y humano, los que tratan de verla como una pura construcción verbal, un gigantesco edificio vacío creado por una inteligencia fría y deshumanizada, olvidando no sólo que la inteligencia es muy exactamente una característica exclusiva del hombre y como tal esencialmente humana, sino además, todo un aspecto de su obra que es el que mejor puede conducirnos a llegar a su último sentido (García Ponce 1964, p. 23).

Como no tengo espacio para entrar en la descripción de algunos rasgos de la fina lectura de García Ponce, me conformaré con señalar que entre los muchos caminos posibles para mostrar que la literatura borgeana es también un arte humanizado, él eligió buscar en ella lo que llamaba la "enorme autobiografía" del autor. De manera tácita, García Ponce intentaba refutar a algunos detractores mexicanos de Borges, entre ellos a Jaime García Terrés, quien en 1961 lo había criticado duramente. Al declarar de entrada su desagrado por la obra de Borges, 
García Terrés había intentado fundar su postura en las siguientes reflexiones:

Mi querella general es ésta: en Borges se consuma la perversidad de una inteligencia inhibida y replegada en una especie de vacío autosuficiente... Los personajes de Borges carecen de alma y cuerpo; son puros nombres enlazados con otros nombres... Si Borges pecara por agobio de la carne, tales abismos serían humanos y llevaderos. Su pecado, al contrario, es inteligencia pura; es un lejano resabio del pecado angélico. En ello estriba su cruel impostura, y también su indiscutida -pero no envidiable- grandeza (García Terrés 1961, p. 163).

Curiosamente, García Terrés presagia la famosa actitud asumida por Octavio Paz, quien en el profundo ensayo "El arquero, la flecha y el blanco", publicado apenas dos meses después de la muerte del argentino (acaecida el 14 de junio de 1986), ejecuta, con una excelente prosa poética, un artículo que bien podría titularse "Menoscabo y grandeza de Borges" (a semejanza del que éste escribió sobre Quevedo en la década de 1920). Si bien Paz reconoce con justicia las enormes aportaciones borgeanas a nuestra lengua, critica que este escritor no haya entrado a lo que considera uno de los grandes temas de la literatura:

Tal vez la literatura tiene sólo dos temas; uno, el hombre con los hombres, sus semejantes y sus adversarios; otro, el hombre solo frente al universo y frente a sí mismo. El primer tema es el del poeta épico, el dramaturgo y el novelista; el segundo, el del poeta lírico y metafísico. En las obras de Borges no aparece la sociedad humana ni sus complejas y diversas manifestaciones, que van del amor de la pareja solitaria a los grandes hechos colectivos. Sus obras pertenecen a la otra mitad de la literatura y todas ellas tienen un tema único: el tiempo y nuestras renovadas y estériles tentativas por abolirlo (Paz 1986, p. 29).

Pero quizá él no hurgó bien en la obra de Borges, sobre todo en su poesía primigenia, donde es más probable encontrar ese tema; aunque también se halla en su narrativa, por ejemplo en una de las declaraciones literarias de amor más profundas y tal vez más patéticas que pueda haber, cuando en un momento climático de "El Aleph", esa entidad ficticia de sí mismo creada por el autor, manifiesta frente al retrato de la amada ya muerta: "Beatriz, Beatriz Elena, Beatriz Elena Viterbo, Beatriz querida, 
Beatriz perdida para siempre, soy yo, soy Borges" (Borges 1996, t. 1, p. 623).

Ahora bien, si se analiza la recepción de Borges en México, se notará que, más allá de comentarios críticos a favor o en contra, muy pronto algunos escritores acusaron su influjo creativo, empezando por Juan José Arreola ${ }^{1}$, quien se benefició de la incipiente fama del argentino, cuyos textos, sobre todo los difundidos por la revista Sur (y luego editorial del mismo nombre) eran ya conocidos en la cultura hispanoamericana a fines de la década de los años 40, es decir, antes de que se convirtiera en el autor de Ficciones (1944) y El Aleph (1949), dos de las colecciones narrativas más influyentes en las literaturas de Occidente. Arreola recuerda así el inicio de su familiaridad -y la del grupo al que pertenecía- con la literatura borgeana:

La experiencia Jorge Luis Borges ocurre, aunque con algún antecedente, en 1942 y 1943 en Guadalajara y en compañía de Arturo Rivas Sáinz. Juntos descubrimos Historia universal de la infamia... Importa resaltar que en Guadalajara se formó un círculo o colegio de borgistas o borgesistas. El primer círculo de lectores de Borges, o mejor, de conocedores de Borges, no ocurrió en México: sucedió en Guadalajara. Junto a Arturo Rivas Sáinz estaban Adalberto Navarro Sánchez, Antonio Alatorre y un hombre llamado Juan Rulfo. Lo esencial fue descubrir en los libros de Borges la sintaxis profunda del español (apud Campos 2002, pp. 165-166).

Para corroborar este dato, en una ocasión se lo pregunté oralmente a otro gran admirador de Borges: Antonio Alatorre, quien lo confirmó. Esto prueba que la primera recepción del escritor argentino en México se produjo fuera del centralismo cultural típico de la ciudad más grande del país. Todavía más notable resulta que su obra haya resonado en la primera ciudad de la provincia mexicana en coincidencia plena con la polémica sudamericana sobre la naturaleza de la literatura practicada por el autor. En efecto, en la década de 1940 se generó en Argentina una fuerte discusión debido a que con su libro El jardín de senderos que se bifurcan (1941), Borges no obtuvo ninguno de los tres lugares del Premio Nacional de Literatura para el trienio 19391941. En respuesta a los detractores de esa decisión, Roberto Giusti, el presidente del jurado que asignó los premios, escri-

${ }^{1}$ Desde su título, este trabajo pretende continuar otro sobre las relaciones entre Borges y Arreola (Olea Franco 2006). 
bió: "Se nos ocurre que quizás quienes se decidan a leer el libro hallen esa explicación en su carácter de literatura deshumanizada, de alambique; más aún, de oscuro y arbitrario juego cerebral..." (Giusti 1942, p. 115). Como se ve, en cierto sentido, las opiniones de García Terrés y Paz habían tenido antecedentes.

\section{"Hombre DE LA ESQUINA ROSADA"}

$\mathrm{Si}$, como indican los testimonios de Arreola y de Alatorre, Juan Rulfo (1917-1986) fue también uno de los lectores iniciales de Borges, cabe preguntarse qué obras de éste pudo haber conocido en esos albores del decenio. Sólo dos: 1) la colección de relatos mencionada por Arreola: Historia universal de la infamia (1935), que en su mayoría habían sido publicados de forma individual entre 1933 y 1934 en la Revista Multicolor de los Sábados del diario Crítica, en una sección bajo ese mismo título, y 2) la Antología de la literatura fantástica, compilada por Borges, Bioy Casares y Silvina Ocampo en 1940; una tercera posibilidad serían los híbridos escritos de Borges en la revista Sur, empezando por "Pierre Menard, autor del Quijote", de 1939, texto inaugural de la serie que se convertiría en el citado libro El jardín de senderos que se bifurcan, el cual en 1944 perdió su autonomía para sumarse como primera parte de la colección Ficciones ${ }^{2}$. En este trabajo me interesa establecer una comparación entre un cuento de Historia universal de la infamia y otro de "El Llano en llamas" y otros cuentos, como en un principio se llamó el libro de Juan Rulfo publicado en 1953, el cual, en mi opinión, posee un estatuto estético similar al de Pedro Páramo. Procederé primero a analizar algunos aspectos del relato del argentino.

En el prólogo de Historia universal de la infamia, Borges califica el volumen como "ejercicios de prosa narrativa". El índi-

2 Aunque por ahora sería imposible rastrear las lecturas borgeanas de Rulfo, en la biblioteca del autor mexicano que se logró preservar abundan las obras de Borges, empezando por la edición de El Aleph impresa por Losada en 1952 (también hay una de 1969), y siguiendo por la colección de Emecé denominada Obras completas de Jorge Luis Borges, de la cual hay varios volúmenes: 1: Historia de la eternidad (1953); 2: Poemas (1954); 3: Historia universal de la infamia (1954); 5: Ficciones (1956), 6: Discusión (1957), además de la primera edición de Otras inquisiciones (1952) y otros libros más. De seguro también hay ejemplares de la revista Sur. Arreola no consigna a quién pertenecía la edición original de Historia universal de la infamia que los acercó al escritor argentino. 
ce enlista tres disímiles secciones: a) siete relatos seriados con números romanos, $b$ ) "Hombre de la esquina rosada", cuyo título provisional en 1933 había sido "Hombres de las orillas", y c) una sección denominada "Etcétera", de la cual el autor asevera que no tiene más derechos que los de "traductor y lector" (Borges 1935, p. 6), pues en ella se reproducen cinco fragmentos provenientes de textos ajenos. Todos los personajes de los siete primeros relatos tienen nombre extranjero y su trama se ubica fuera de Argentina: Lazarus Morell, Tom Castro, la viuda Ching, Monk Eastman, Bill Harrigan, Kotsuké no Suké y Hákim de Merv. Asimismo, la página del "Índice de las fuentes", que constituiría la mínima cuarta sección del índice general, enumera las variadas obras en las que Borges abrevó para construir esos relatos, algunas de divulgación, ámbito que él siempre valoró y aprovechó. En contraste, el narrador y a la vez personaje de "Hombre de la esquina rosada" es anónimo y su historia transcurre en Buenos Aires, además de que no se indica ninguna fuente para este texto (de hecho, en ediciones posteriores el "Indice de las fuentes" apareció antes del cuento, con lo cual se implicaba su nula relación con él). Años después, en Un ensayo autobiográfico, redactado en inglés en 1970, con el apoyo de Norman Thomas de Giovanni, Borges declaró que se trataba del único cuento del conjunto (1999, p. 75); también es el único cuyo mundo de ficción tiene referentes netamente argentinos o, más en concreto, criollo-gauchescos. Su bien conocida anécdota se puede resumir así: con un marcado tono coloquial, un narrador anónimo cuenta cómo un hombre apodado el Corralero invade su barrio para desafiar al líder de su grupo, Rosendo Juárez, quien pese a su fama de valiente, rehúsa la pelea, a la cual incluso lo impele su mujer, la Lujanera, sacándole de entre la ropa su cuchillo, que él no empuña sino que lo arroja al arroyo a través de la ventana. El Corralero sale triunfante del salón-cantina llevándose a la mujer en medio del baile, luego de lo cual Rosendo también abandona el sitio, mientras empuja e insulta al narrador, a quien califica como un simple estorbo; minutos después, el Corralero regresa con una herida de muerte en el pecho, inferida por un hombre que lo desafió a pelear a cuchillo. Como el moribundo no puede hablar, la Lujanera explica que después de salir ambos, un desconocido hirió al Corralero en una lucha a cuchillo. Al final, el anónimo narrador describe los últimos momentos del finado y dice con orgullo que esa noche la Lujanera se fue a dormir con él, 
y acaba insinuando a su interlocutor, llamado "Borges", que él fue el asesino.

Desde 1927, Borges había buscado el modo apropiado para contar una historia de cuchilleros, la cual pasó por múltiples anécdotas y títulos, los ya mencionados y dos previos: "Leyenda policial" (1927) y "Hombres pelearon" (1928). Tardó varios años en encontrar la perspectiva y el tono necesarios para un relato así, pues en sus primeros bosquejos había acudido a un ineficiente narrador en tercera persona, casi un testigo, que describía los sucesos desde una perspectiva y una voz externas poco convincentes. En su ensayo de 1950 titulado Aspectos de la literatura gauchesca, en medio de sus reflexiones sobre este género típico de la cultura del Río de la Plata, de pronto Borges introduce una confesión muy personal: "En mi corta experiencia de narrador, he comprobado que saber cómo habla un personaje es saber quién es, que descubrir una entonación, una voz, una sintaxis peculiar, es haber descubierto un destino" (Borges 1950, p. 8). Aunque no precisa el dato, se refiere al proceso de escritura de "Hombre de la esquina rosada", uno de sus pocos textos narrativos donde la voz enunciadora es ajena al mundo cultural del propio autor. Así pues, la definición formal de este cuento se produjo cuando él cedió la palabra al personaje, lo cual no es tan sencillo como parece. A diferencia de algunos novelistas actuales (varios de ellos con notable éxito comercial), que suelen adjudicar el mismo tipo de voz a todos los personajes, en su ejercicio de la prosa narrativa, Borges aprendió que el habla de cada personaje debe ser coherente con su caracterización general. Los siete relatos que anteceden "Hombre de la esquina rosada", todos ellos con protagonistas extranjeros que además son seres marginales (social o culturalmente), sólo podían forjarse mediante un narrador externo que, si acaso, parafrasea en español (a partir de las versiones en inglés o alemán consultadas y traducidas por Borges) lo que habrían dicho los personajes; a ello se añaden algunas frases signadas por una mirada local; así, por ejemplo, se describe a un gánster de Nueva York con un símil proveniente de una imagen de la pampa: "[Monk Eastman] solía recorrer su imperio forajido con una paloma de plumaje azul en el hombro, igual que un toro con un benteveo en el lomo" (Borges 1935, p. 56).

En cambio, "Hombre de la esquina rosada" se afilia, grosso modo, a la tradición gauchesca, la que desde sus orígenes se caracteriza por simular que quien narra (en verso o en prosa) 
es un gaucho, convención o artificio aceptado sin cuestionar por los oyentes o lectores. En gran medida, esto se debe a que se trata de una variante asociada a cierto tipo de realismo. Por ello, según declaró el autor varias veces, la escritura del texto requirió la repetición de las frases en voz alta, hasta alcanzar el tono oral pertinente para el personaje; este cuidado proceso implica siempre una simulación estética, porque, como afirman ahora algunos críticos, se trata de una "oralidad fingida": "La «oralidad fingida» crea la ficción o la ilusión de un habla auténtica que, en general, caracteriza la manera de hablar de una figura o protagonista imaginado" (Brumme 2008, p. 9).

En 1925, mediante la singular poesía de Luna de enfrente, luego muy modificada, Borges había intentado llevar la oralidad a la escritura (con exiguo éxito, por cierto, porque no logró un tono semejante al de Martín Fierro, de José Hernández, quien había acudido a una forma métrica tradicional de la cultura oral y popular, la sextilla, con su estructura en octosílabos con rimas en los versos pares). A veces la crítica textual carece de datos para discernir si las palabras en cursivas o entre comillas visibles en un libro fueron marcadas así por el autor. En el caso de Borges, cabe destacar que la grafía de sus textos no señala la oralidad con ningún signo tipográfico que pretenda mostrar algunas voces como ajenas a una implícita norma lingüística. Además, en las grafías fonéticas del narrador en primera persona de "Hombre de la esquina rosada", casi siempre se reconoce de inmediato la palabra original: laos, acreditao, soledá, amistá, voluntá, usté, paré[d], colorao, oservé, inoraba, esperiencia, jué, juí, ajuera, dijunto, güen, peliar, pisotiando, naides, etcétera. Por eso Noemí Ulla afirma: "La sintaxis del texto borgeano tiene las características del habla popular gauchesca, de modo que las diferencias en la construcción, en el régimen y en la concordancia no llegan a alterar la lengua, a pesar de la presencia de construcciones elípticas, ambiguas, anacolutos, asíndeton y polisíndeton" (Ulla 1990, pp. 124-125). Asimismo, no obstante el ambiente marginal del mundo de ficción y de los seres que lo pueblan, el vocabulario del texto muestra una escasa influencia del lunfardo, es decir, de la jerga o caló usado por parte de los estratos populares de Buenos Aires (incluyendo la delincuencia), variante social a la que el autor había dedicado varios ensayos; entreverados en un cúmulo de voces criollas, sólo aparecen escasos términos lunfardos ("quilom- 
bo", "lengue", "biaba") y uno solo italiano ("facha"). Del mismo modo, Borges se aleja de la rural lengua gaucha, por lo que en sus voces predomina más bien un fuerte sabor criollo de carácter semiurbano. Tanto su obra como la literatura gauchesca construyen una oralidad literaria, pero de modos distintos: la primera recrea artísticamente la oralidad criolla de los compadritos de las orillas; la segunda, el habla de los gauchos del campo.

En su seminal estudio sobre la literatura gauchesca (1988), Josefina Ludmer indica que este género se caracteriza por dos rasgos coincidentes: el tono del desafío y el tono del lamento, visibles por ejemplo en la voz del personaje de la primera parte del Martín Fierro, de 1872. Desde Evaristo Carriego (1930), Borges rechaza con entusiasmo el segundo tono, al que incluso denomina con un término despectivo, pues cuando describe la tendencia de Carriego a retratar las penurias de barrio, critica: "Carriego se estableció en esos temas, pero su exigencia de conmover lo condujo a una lacrimosa estética socialista, cuya inconsciente reducción al absurdo efectuarían mucho después los de Boedo" (Borges 1930, p. 98). Esa "lacrimosa estética socialista" respondería al siguiente esquema: usando un tono sentimental basado en el lamento, un escritor muestra las miserias vitales de algunos seres desposeídos, con lo cual busca provocar la inmediata empatía de sus lectores, en quienes desea generar piedad o compasión. La renuncia a ese rasgo constitutivo de la gauchesca refuerza la amoralidad del crimen visible en varios textos borgeanos, a cuyos personajes simplemente les "sucede" asesinar. Ricardo Piglia resume con certeza lo que Borges entiende como la tradición gauchesca: "La oralidad, digamos entonces, la sintaxis oral, el fraseo, el decir nacional. Y por otro lado el culto al coraje, el duelo, la lucha por el reconocimiento, la violencia, el corte con la ley. Eso es la gauchesca para Borges" (Piglia 2001, p. 76).

Ahora bien, si Borges tardó varios años en encontrar esa escritura, también le tomó tiempo armarse de valor para confesar a su familia su atracción por esos temas marginales, alejados de la moral de la pequeña burguesía argentina. Interesarse por un gánster de Nueva York, un pistolero del medioeste, una pirata china, etc., podría ser un simpático rasgo exótico dentro de la cultura argentina de la época, y quizá por ello mismo era permisible. En cambio, un cuchillero de la zona fronteriza entre la 
urbe porteña y la pampa no tenía la sanción debida ${ }^{3}$. De hecho, el autor no incluyó la versión inicial de lo que sería "Hombre de la esquina rosada" (que, como ya dije, se tituló "Hombres pelearon") bajo la sección "Historia universal de la infamia" del diario Crítica; tampoco la firmó con su nombre sino con el seudónimo de F. (Francisco) Bustos, uno de sus antepasados, porque temía provocar disgusto en su familia por esa vertiente de su literatura. En una entrevista de la década de 1950, James Irby testimonió cómo la madre del autor difería de sus gustos estéticos, pues mientras ella alababa Don Segundo Sombra (1926), de Ricardo Güiraldes, Borges sentía una fuerte atracción por el Martín Fierro, en particular por la primera parte; como "madre" (Borges siempre se refirió a ella así) se escandalizaba porque a Georgie le gustaran esas historias de los bajos fondos porteños, Irby (1968) planteó un "Posible tema para los futuros investigadores de la vida de Borges: el populismo de éste como una reacción en contra del mismo ambiente familiar respetable y cosmopolita que le ha proporcionado el refinamiento necesario para su arte" (p. 18) ${ }^{4}$. En cierto sentido se podría decir que la superación plena de este sentimiento ocurrió muchos años después, en 1970, con su relato "Historia de Rosendo Juárez".

En "Hombre de la esquina rosada", Rosendo aparece como mero personaje referido, a quien el narrador anónimo describe como un cobarde que rehúsa enfrentarse al Corralero, el invasor que llega al barrio sólo para provocarlo porque sabe de su fama de valiente. Pero en "Historia de Rosendo Juárez", éste asume la voz para contar al narrador, otro alter ego de Borges, por

3 A diferencia de su poesía de la década de 1920, en la cual el ejercicio de la violencia se ligaba con las heroicas y trascendentes luchas por la patria, representadas por sus antepasados militares, cuyas acciones e importancia la voz poética hiperboliza, la práctica del valor y del coraje visible en algunos personajes de sus narraciones se circunscribe a un ámbito individual.

${ }^{4}$ En el transcurso de varias conversaciones que sostiene con Borges, James Irby nota que en el plano literario el autor se distancia del "criterio aristocrático" de su madre: aunque comparte con ella su conciencia de abolengo distinguido y su horror a la vulgaridad, también idealiza esas "imágenes populares del coraje ilícito" que repugnan a su madre. Del mismo modo, su valoración de Don Segundo Sombra y del Martín Fierro es diferente: para la madre, el último es apenas una vulgar "payada" y su autor poco menos que un gaucho cualquiera, mientras considera que la novela de Güiraldes es la obra refinada de un autor culto; Borges, por su parte, fracasa en su intento por mostrar a su madre la mayor riqueza y profundidad del poema de Hernández. 
qué no aceptó el desafío. En un momento de su narración oral, Rosendo describe así a alguien que, por instrucciones del caudillo Nicolás Paredes, redacta una carta de recomendación: "La carta se la escribió un mocito de negro, que componía versos, a lo que oí, sobre conventillos y mugre, asuntos que no son del interés de un público ilustrado" (Borges 1996, t. 2, p. 412). Ese mocito vestido de negro es, obviamente, Evaristo Carriego, cuyo nombre está ausente, pero no así su caracterización, elaborada mediante rasgos provenientes de Evaristo Carriego. En cuanto a la incipiente crítica literaria practicada por Rosendo, se trata de un sano rasgo autoirónico, porque, en efecto, el medio al que pertenecía Borges, es decir, el "público ilustrado", no debería interesarse por los asuntos de las orillas y los cuchilleros.

\section{"La Cuesta de las Comadres": un diálogo con Borges}

La hipótesis central que deseo proponer en este trabajo es que Rulfo fue un aventajado lector de "Hombre de la esquina rosada", texto del que encuentro huellas en el tercer cuento de $E l$ Llano en llamas: "La Cuesta de las Comadres". Este último se publicó por vez primera en febrero de 1948, en la revista América, la cual desde varios años atrás venía difundiendo algunos cuentos de Rulfo ${ }^{6}$. Cabe recordar que uno de los primeros relatos que, con renuencia, dio a la imprenta fue "Nos han dado la tierra", que apareció en Guadalajara en la revista Pan de Arreola y Alatorre (julio de 1945); sobre esta narración del silencioso Rulfo, Arreola manifestó con admiración:

Cuando la leí recuerdo que me dije: si éste sigue así, va a acabar con el cuadro. Percibí en Rulfo lo que puedo describir como una fuerza oblicua, semejante al trote del coyote. Tanto él como sus

${ }^{5}$ La obra de Borges y Rulfo ha sido analizada en conjunto desde diferentes perspectivas. Por ejemplo, Fernando De ToRo (1999) acude a ella para discutir su probable adscripción al concepto de posmodernidad. Como se verá, mi enfoque es más directo y textual.

${ }^{6}$ En una carta del 28 de enero de 1948 a su prometida Clara Aparicio, Rulfo le anuncia, en un tono modesto y jocoso, la inminente lectura de su texto en una estación de radio: "Se me olvidaba decirte que mañana (miércoles) a las siete y media van a leer algunos pedazos por la XEX de mi último mamarracho, aquel que yo te platiqué que se iba a llamar «La Cuesta de las Comadres». En esa radiodifusora les gusta mucho mortificar a la gente buena que quiere estar tranquila" (RULFo 2000, p. 231). 
personajes parecían ver las cosas, juzgarlas de una manera oblicua, al sesgo, yo diría que en bies. No había una recta en su pensamiento o en su modo de contar las cosas, sino un diagonalismo, un espíritu de alfil (Arreola 1996, p. 119).

Como suele suceder con muchas obras clásicas, la trama de Rulfo es tan sencilla como la de Borges: en una especie de extraño monólogo interior donde se introducen diálogos, un narrador anónimo rememora su relación de complicidad con dos hermanos ladrones y asesinos apellidados Torrico, así como la muerte violenta de ambos. El cuento del argentino empieza: "A mí, tan luego, hablarme del finado Francisco Real. Yo lo conocí, cuándo no, y eso que éstos no eran sus barrios porque él sabía tallar más bien por el Norte, por esos laos de la laguna de Guadalupe y la Batería" (Borges 1935, p. 97); en el cierre, el lector sabrá que, efectivamente, el narrador "conoció" a Francisco Real, el Corralero, pues incluso lo asesinó la única vez que lo trató. El de Rulfo inicia: "Los difuntos Torricos siempre fueron buenos amigos míos. Tal vez en Zapotlán no los quisieran; pero, lo que es de mí, siempre fueron buenos amigos, hasta tantito antes de morirse" (1953, p. 22). Así pues, en ambos casos el narrador declara haber conocido al finado y es quien eventualmente se revelará como un asesino; en Rulfo esto se produce a la mitad del relato, en Borges al final.

Si bien en los dos textos hay un sutil manejo de la ironía, ésta resulta más aguda en el mexicano, porque los difuntos Torricos eran buenos amigos (más bien cómplices) del narrador, hasta "tantito" antes de morirse; aunque ningún ser humano puede ser amigo de otro después de su muerte, este aparente pleonasmo encubre que el narrador es el verdugo de uno de los hermanos Torrico, quien más bien se convierte en su enemigo "tantito" antes de ser ultimado. Además, el escritor usa con sagacidad la forma reflexiva de la lengua española, en la frase "antes de morirse", mediante la cual se esconde a los agentes de las acciones, o sea, el asesinato de los hermanos Torrico, a manos de distintos homicidas y en momentos diferentes. En suma, este pasaje funciona como indicio del destino de uno de los Torricos, aunque disfrazado por su presunta amistad con el narrador. En Borges también hay indicios que apuntan a la identidad del hombre que acuchilla al Corralero, entre ellos el hecho de que el narrador anónimo asuma como una grave ofensa personal la cobardía de Rosendo, a quien antes consideraba 
un valiente; en cierto sentido, al final se restituye el orden, porque la muerte del Corralero implica un acto de justicia reivindicativa: de ese modo se borra el acto vergonzoso de Rosendo, que había manchado a todos los miembros de su grupo de amigos y admiradores, según se deduce por la reacción del narrador.

Asimismo, ambos autores trabajan desde la oralidad, de fuerte entonación rural en el mexicano y orillera en el argentino (es decir, la confluencia entre las orillas de la urbe y los inicios de la pampa). Con enorme habilidad, Rulfo inventa un habla propia para cada uno de sus personajes, en este caso el protagonista y narrador en primera persona, quien a su vez reproduce con exactitud las palabras ajenas, representadas mediante las marcas tipográficas de un diálogo directo. Pero al reconocer esta capacidad creadora, debe uno precaverse del inocente y frecuente error de aseverar que los personajes de Rulfo hablan igual que los seres de carne y hueso de la zona del sur de Jalisco, cuya representación literaria él imagina. Como examina en detalle Françoise Perus en su excelente libro sobre el arte narrativo de Rulfo (2012), esa pretendida "oralidad" es uno más de los extraordinarios efectos de una compleja y elaborada escritura.

En su aspecto verbal, la pericia de un escritor reside en lograr que el habla de sus personajes parezca verídica, calcada de modelos reales, como apreció con certeza Arreola, quien luego de afirmar que Rulfo se apoya en el color local, concluye:

Sin embargo, a partir de ese color local Rulfo fue capaz de crear un lenguaje que no es el del sur de Jalisco, sino una lengua literaria muy curiosa, inventada, llena de cultismos. Lo que sucede es que Rulfo es convincente. Lo convence a uno de que los personajes de los que parte hablan así en realidad (Arreola 1996, p. 163).

Para alcanzar este efecto, el autor asumió un consciente trabajo de estilo, según declaró a Sommers en una entrevista donde cifró su búsqueda de la forma de expresión:

Tenía yo los personajes y el ambiente. Estaba familiarizado con esa región del país, donde había pasado la infancia, y tenía muy ahondadas esas situaciones. Pero no encontraba un modo de expresarlas. Entonces simplemente lo intenté hacer con el lenguaje que yo había oído de mi gente, de la gente de mi pueblo. Había hecho otros intentos -de tipo lingüístico-que habían fracasado porque me resultaban un poco académicos y más o menos falsos. Eran incomprensibles en el contexto del ambiente donde yo 
me había desarrollado. Entonces el sistema aplicado finalmente, primero en los cuentos, después en la novela, fue utilizar el lenguaje del pueblo, el lenguaje hablado que yo había oído de mis mayores, y que sigue vivo hasta hoy (apud Sommers 2003, p. 518).

El interés del escritor por la lengua oral de su región se había manifestado desde antes de que abrazara la profesión literaria, como recuerda su hermano Severiano, quien testimonia que cuando Juan volvía a su tierra:

Platicaba él mucho, en las noches, con los rancheros, los mozos y los vaqueros. Con los arrieros que iban o venían de Sayula o de Zapotlán, también debió platicar mucho. Entonces había mucho movimiento allí. Había mesones, comercios y fondas. Yo llegaba cansado a acostarme y él se quedaba platicando (apud Cobián Rosales 1986, p. 58).

Quizá por ello los arrieros tienen tan destacada presencia en su narrativa, empezando por "La Cuesta de las Comadres" (así sea tan sólo en calidad de víctimas, como es el caso). Borges, en cambio, había aprendido (más que vivido) esa oralidad, pues no era cercano a sus emisores; parte de este conocimiento derivó de sucesivas conversaciones con el caudillo de barrio Nicolás Paredes, una vez que éste se había retirado un tanto de la acción directa (véase Williamson 2006, pp. 198-200). Según Bioy Casares, Borges le habría dicho: "A Paredes lo conocí cuando buscaba datos para mi libro sobre Evaristo Carriego" (Bioy Casares 2006, p. 1092). De hecho, en varias entrevistas posteriores, sobre todo en su madurez, el escritor se lamentó de haber usado en "Hombre de la esquina rosada" palabras cuyo significado exacto ya no comprendía; de ello se podría deducir que, aunque en menor grado, también procedió como en Luna de enfrente, obra poética para cuya composición incluso consultó un diccionario de argentinismos. La lengua de Rulfo, por el contrario, parece (y suena) más "natural", entendiendo, claro está, que en literatura todo es artificio. Creo que en "La Cuesta de las Comadres" sólo hay una palabra transcrita al modo culto: "desavenencias", que, si no me equivoco, en el lenguaje popular suele ser pronunciada como "desaveniencias" (¿o acaso yo la pronuncio así y por ello considero que eso es lo más común?).

En varios de sus proscritos o muy corregidos libros de la década de 1920, Borges dejó huellas de su aprendizaje, en espe- 
cial en su manejo de la lengua. El caso de Rulfo es distinto, porque hay pocos vestigios textuales de la elaboración de sus cuentos; a primera vista, aparenta ser un escritor que no experimentó un proceso de aprendizaje. Quizá por ello causó recelo entre cierto sector de la república de las letras, sorprendido por la irrupción de una voz literaria cuya destreza no sólo se mostró desde su arranque mismo, sino que incluso no ha sido desmentida por la difusión de las versiones sucesivas de los textos, donde hay escasas modificaciones estilísticas; aquí conviene citar de nuevo a Arreola, quien sintió como un privilegio ser el lector inaugural de algunos cuentos rulfianos, en los que no detectó nada que debiera corregirse:

Tuve así la alegría, en varias ocasiones, de ser el primer lector de un cuento recién escrito por Juan. Y cosa curiosa, yo, que siempre revisaba los textos de otros, y que a todos les hacía alguna sugerencia o alguna corrección, a Juan jamás me atreví a decirle nada (Arreola 1996, p. 121) ${ }^{7}$.

En "El desafío de la creación”, una de sus esporádicas reflexiones sobre su experiencia personal en el proceso del trabajo literario, Rulfo describe el aspecto lingüístico de sus personajes como un elemento sustancial: "Considero que hay tres pasos: el primero de ellos es crear el personaje, el segundo crear el ambiente donde ese personaje se va a mover y el tercero es cómo va a hablar ese personaje, cómo se va a expresar" (Rulfo 2007, p. 388); quizá él se habría sumado a la idea borgeana de que definir el habla de un personaje es encontrar su destino. Como dije, "La Cuesta de las Comadres" no es uno de los primeros cuentos de Rulfo, quien ya para entonces manejaba con mayor soltura ese extraordinario estilo que lo caracteriza, en que las expresiones de raigambre oral campirana se combinan con una prosa poética con el mismo sabor, empezando

7 Arreola precisa que sólo una vez se atrevió a emitir un consejo: que era poco verosímil una expresión del final del cuento "Anacleto Morones", cuando un personaje femenino declara que Anacleto sí sabía "hacer el amor". Según él, no era lógico que una mujer de San Gabriel hablara así, aunque cuando el texto apareció sin ningún cambio, él comprendió que la frase era sinónimo de "cortejar", como se entendía en aquella época. Por mi parte, sospecho que el comentario de Arreola más bien sirvió como acicate para que Rulfo reafirmara su deseo de usar esa ambigua y rica frase, que significa tanto "cortejar" como "tener relaciones sexuales" con alguien, como de hecho se percibe en "Anacleto Morones". 
por sus recursos provenientes de la oralidad popular, con frases breves y autónomas que incluso forman octosílabos, como: "Pero nadie regresó" o "Fue cosa de un de repente".

Así como el argentino temía incomodar a su familia por sus personajes marginales, Rulfo recibió comentarios negativos por los temas tratados en sus textos. En 1958, Alberto Valenzuela elaboró una nota titulada "Nuevos ingenios mexicanos", donde hablaba de cuatro recientes y destacados escritores: Octavio Paz, Juan Rulfo, Juan José Arreola y el ahora desconocido David N. Arce. En su valoración de El Llano en llamas, Valenzuela asume una postura moralizante, ajena a criterios estéticos:

Pero es bien de dolerse que un hombre tan finamente dotado y tan fiel receptor de vibraciones telúricas (conoce evidentemente el terruño) no haya sabido captar sino la onda roja. Y es una verdadera desgracia que [Rulfo] escriba bien mientras se dedique a esa literatura depresiva, sin Dios, sin alegría, sin aire respirable (Valenzuela 1958, p. 88).

Este crítico no evalúa el nivel literario de la obra, sino sus temas y personajes, según el prejuicio de que el arte sólo debería tratar asuntos virtuosos; por ello no percibe la contradicción inmanente a su opinión de que Rulfo escribe bien, pero sobre temas poco edificantes (en última instancia, esta misma medida podría aplicarse a una larga lista de grandes escritores, encabezada en el extranjero por Dostoievski y en México por Revueltas, quien ya en 1943 había publicado su novela El luto humano, donde incluso hay un sacerdote asesino). Más comprensivo fue Edmundo Valadés, el gran impulsor del género cuento en México, pues supo distinguir que los relatos de Rulfo, sin asumir un tono didáctico, calaban hondo en la realidad mexicana; por ello, en una reseña titulada "El libro de Juan Rulfo quema las manos", aconsejaba:

[Estos cuentos] Deben ser leídos por todos los mexicanos, ya que en ellos hay una brasa que les ha de quemar las manos como nos las ha quemado a nosotros, para no olvidarse de ese México que necesita de justicia, de pan, de agua, de alfabeto, en síntesis, de una enérgica rehabilitación (Valadés 1953, p. 2).

Juan José Arreola, coetáneo de Rulfo y casi de la misma región del sur de Jalisco, propone un eslabón perdido dentro 
de la genealogía literaria rulfiana: "A través de Cipriano Campos Alatorre, Rulfo se acerca y absorbe a Martín Luis [Guzmán], Mariano Azuela y toda una corriente que viene desde antes, pero no mucho antes" (Arreola 2002, p. 202). En efecto, quien se acerque al extenso relato titulado "Los fusilados", que da nombre al libro completo de Campos Alatorre difundido en 1934, creerá percibir de pronto ecos del tono de Rulfo. En particular, esa probable influencia sería perceptible en la crudeza extrema con que sus respectivos narradores relatan los actos más sanguinarios. En la escena final de "Los fusilados", uno de los tres prisioneros logra sobrevivir a las balas y empieza a correr, pese a estar atado de manos; entonces un soldado lo persigue y lo acribilla con un machete, al tiempo que involuntariamente corta las pencas del maguey detrás de las que el otro se guarece:

Simón se estiraba, se encogía, y daba saltos inverosímiles; pero de pronto se detuvo. Un machetazo había dado en el blanco. Con un hombro casi desprendido, y regando la tierra con su sangre, cayó de rodillas.

-¡Hermano... hermanito! ¡No me vayas a matar!

Un segundo golpe le cortó el brazo derecho, y el tercero lo alcanzó en la cabeza. Se oyó un ruido hueco, extraño, como cuando parten una calabaza, y el cuerpo rodó pesadamente (Campos Alatorre 1934, p. 64).

$\mathrm{Al}$ igual que en los relatos rulfianos, no hay una sola intervención piadosa por parte del narrador, quien se concreta a ser cronista neutral de los hechos, comparando incluso la cabeza hendida del personaje con una calabaza partida. El símil campirano de este pasaje se asemeja a la forma como el narrador anónimo de "La Cuesta de las Comadres" describe el cadáver de un humilde arriero que ha sido asesinado por los Torricos para luego robarle su carga, con el auxilio del narrador: "Ya por último le di una última patada al muertito y sonó igual que si se la hubiera dado a un tronco seco" (Rulfo 1953, p. 27). Por ello sin duda se podría concluir que Rulfo tampoco practica la "lacrimosa estética socialista".

Ahora bien, el anonimato de la voz se mantiene hasta la conclusión de "Hombre de la esquina rosada" y de "La Cuesta de las Comadres", si bien Rulfo no intenta construir un final sorpresivo respecto de la identidad del asesino, pues a la mitad 
del relato el anónimo narrador adelanta "A Remigio Torrico yo lo maté" (Rulfo 1953, p. 28); este rasgo es consecuente con su poética, donde no suele apostarse por un cierre inesperado. Por su parte, como adelanté, el argentino inscribe varios indicios sobre la identidad del brazo ejecutor del Corralero, aunque el secreto se revela hasta la última frase, cuando el narrador confiesa con orgullo: "Entonces, Borges, volví a sacar el cuchillo corto y filoso que yo sabía cargar aquí, en el chaleco, junto al sobaco izquierdo, y le pegué otra revisada despacio, y estaba como nuevo, inocente, y no quedaba ni un rastrito de sangre" (Borges 1935, p. 113).

Según mi lectura, el anterior final permite establecer una clara relación intertextual entre el relato de Borges y el de Rulfo, en cuyo penúltimo párrafo se lee: "Ya la luna se había metido del otro lado de los encinos cuando yo regresé a la Cuesta de las Comadres con la canasta pizcadora vacía. Antes de volverla a guardar, le di unas cuantas zambullidas en el arroyo para que se le enjuagara la sangre" (Rulfo 1953, p. 33). Así, en el cuento de Borges, al arma homicida no le queda un rastro de sangre, después de que, se infiere, el criminal ha lavado el cuchillo en el agua del arroyo Maldonado; en el de Rulfo, el narrador sumerge la canasta pizcadora en la corriente del arroyo para borrar cualquier resto de sangre. Con base en el personal estilo elíptico de Rulfo, el cual creo que debe mucho a Los de abajo, de Mariano Azuela, tanto la mención de que el personaje ha regresado de realizar algún acto como la canasta vacía sugieren que ésta -no arma homicida pero sí medio de transporte- ha servido para cargar el cadáver aún sangrante de Remigio Torrico, como aclara el texto poco después: “...donde tiré a Remigio se levantaba una gran parvada de zopilotes a cada tronido que daban los cohetes" (1953, p. 33); zopilotes que, se deduce, ayudarán a borrar (o limpiar) las huellas de los sucesos. Antes, el narrador enuncia que ha limpiado la canasta por un mero interés práctico: "Yo la iba a necesitar muy seguido y no me hubiera gustado ver la sangre de Remigio a cada rato" ( $i d$.). El texto enlaza así con un motivo del inicio: los sabrosos elotes cosechados en la Cuesta de las Comadres, cuyo transporte se efectúa con el auxilio de la canasta pizcadora, instrumento campirano de gran tamaño que suele colgarse a la espalda del pizcador, quien recorre la siembra para recolectar los elotes tiernos o las mazorcas macizas (un motivo recurrente en su obra: el campo y sus frutos, en particular el maíz). Esta actitud pragmática delata 
que el narrador no se preocupa por desvanecer las huellas del asesinato, lo cual significa dos cosas: primero, que él no interpreta su acto como un crimen punible, ni siquiera en su conciencia; segundo, que no teme a la ley (la cual, por cierto, no debe confundirse con la justicia).

En este punto hay una gran coincidencia entre la literatura gauchesca tal como la practica Borges y la violencia según se representa en varios cuentos de Rulfo, pues en ambos casos los personajes no expresan la más mínima conciencia de haber cometido un delito. Asimismo, en sus textos se construye un mundo de ficción donde las instituciones del Estado están casi ausentes (consumados los hechos sangrientos, en el relato de Borges apenas se indica: "Cuando echaron su vistazo los de la ley, el baile estaba medio animado”, 1935, p. 112). De ahí a la realidad histórica concreta vivida por estos dos escritores hispanoamericanos sólo hay un paso, aunque conviene precisar que sus protagonistas no enuncian ningún tipo de conclusión, pues como indica Dorfman: "A los personajes de Borges, tal como los de Onetti, Droguett, Rulfo, etc., no se les ocurre negar la agresión, intelectualizarla: la viven, eligen la forma de su violencia pero no el hecho de su violencia" (Dorfman 1970, p. 52). Cabe añadir que, de forma económica y tangencial, el segundo párrafo de "La Cuesta de las Comadres" refiere a un tiempo histórico concreto dentro de la ficción:

Y si no es mucho decir, ellos [los Torricos] eran allí los dueños de la tierra y de las casas que estaban encima de la tierra, con todo y que, cuando el reparto, la mayor parte de la Cuesta de las Comadres nos había tocado por igual a los sesenta que ahí vivíamos... A pesar de eso la Cuesta de las Comadres era de los Torricos (Rulfo 1953, p. 22).

La frase "el reparto" alude a la redistribución agraria de la época posrevolucionaria, mito tan fina e irónicamente representado-y derruido- en "Nos han dado la tierra", el cuento que antecede a "La Cuesta de las Comadres".

En "Hombre de la esquina rosada", varios sujetos despojan de sus pertenencias al Corralero antes de que su cuerpo sea arrojado al arroyo por la misma ventana que usó Rosendo para lanzar el cuchillo temeroso: "Lo levantaron entre muchos y de cuanto centavo y cuanta zoncera tenía, lo alijeraron esas manos y alguno le hachó un dedo para refalarle el anillo" (Borges 
1935, p. 112). La última expresión de esta secuencia delatora de la miseria humana apunta a "La Refalosa", del poeta gauchesco decimonónico Hilario Ascasubi, quien en versos de pie quebrado (octosílabos combinados con tetrasílabos) construyó un texto en el que un miembro de la policía represiva del dictador argentino Juan Manuel de Rosas, que dominó la región entre 1829 y 1852, se jacta de cómo torturan con deleite a un enemigo político, un "salvaje" unitario, hasta darle muerte. El término "refalosa" (o "resbalosa") remite a un tipo de canción popular del siglo xix con ese nombre, el cual se le asignó porque los danzantes resbalaban los pies en el piso al desplazarse; en el poema popular de Ascasubi, se menciona que el acto de tortura es, musicalmente, una refalosa; además, se usa como verbo, cuando se indica cómo concluye la tortura contra un hombre amarrado e inerme:

$$
\begin{gathered}
\text { ¡Qué jarana! } \\
\text { nos reímos de buena gana } \\
\text { y muy mucho, } \\
\text { de ver que hasta les da chucho; } \\
\text { y entonces lo desatamos } \\
\text { y soltamos; } \\
\text { y lo sabemos parar } \\
\text { para verlo refalar } \\
\text { ¡en la sangre! } \\
\text { hasta que le da un calambre }
\end{gathered}
$$

(Ascasubi 1872, p. 133).

Además del significado de "resbalar", el verbo "refalar", sin registro en el actual diccionario de la Academia de la Lengua, posee otro sentido: "Quitar, despojar a alguien de algo", propio de Chile y del Río de la Plata, tal como anotó hasta 1989 el Diccionario manual e ilustrado de la lengua española (s.v.); también aparece en varios diccionarios de americanismos o argentinismos, con la misma acepción. Por ello, el narrador del cuento de Borges dice que alguien le hachó un dedo al muerto para "refalarle" ("robarle") el anillo. Esta acción, descrita con la mayor naturalidad, sirve como contraste para ensalzar al desinteresado valiente que venció al Corralero, en un autoelogio que el narrador encubre con una falsa compasión por el muerto: "Aprovechadores, señor, que así se le animaban a un pobre dijunto indefenso después de que lo arregló otro más hombre" (Borges 1935, p. 112). 
En "La Cuesta de las Comadres", el texto sugiere, con extraordinaria sutileza, que Remigio Torrico reclama al narrador anónimo su probable (y luego desmentida) injerencia en el asesinato de su hermano Odilón no por afecto fraterno, sino por una causa miserable, expresada en dos momentos, transcritos en forma de diálogo por el narrador, a quien primero Remigio reclama: “-... Odilón llevaba ese día catorce pesos en la bolsa de la camisa. Cuando lo levanté, lo esculqué y no encontré esos catorce pesos. Luego ayer supe que te habías comprado una frazada" (Rulfo 1953, p. 30), y poco después: “-Odilón y yo éramos sinvergüenzas y lo que tú quieras, y no digo que no llegamos a matar a nadie; pero nunca lo hicimos por tan poco. Eso sí te lo digo a ti” (p. 31). Así pues, a Remigio no le duele la muerte de su hermano Odilón, sino el hecho de que, antes de que él esculcara el cadáver, alguien más lo haya "aligerado" de esos catorce pesos que él supone costearon la compra de la frazada del narrador. Con la misma economía, Rulfo inscribe la cínica y a la vez inocente confesión de Remigio como asesino, encubierta bajo una justificación material: lo malo no es matar, sino hacerlo por tan poco dinero. "Robar" y "matar", los dos verbos de la sicología mexicana, según manifiesta con desencanto Alberto Solís, personaje de Los de abajo, se presentan conjugados en "La Cuesta de las Comadres".

En los textos estudiados, los asesinos acuden al auxilio de un arma punzocortante ${ }^{9}$, aunque no por causas idénticas: en "Hombre de la esquina rosada", se trata de una acción de venganza (grupal, más que individual, según el narrador), buscada deliberadamente; en "La Cuesta de las Comadres", casi de un acto reflejo, porque cuando un amenazante Remigio Torrico toma el "guango" (o sea, el machete) del narrador, éste recibe la inspiración de la luz de la luna, que en una clara función de destinador, ilumina la aguja de arria (es decir, de arriero) con la que él estaba cosiendo un costal: "Y no sé por qué, pero de

${ }^{8}$ He mencionado dos veces a Azuela porque pienso que hay múltiples huellas suyas en la obra rulfiana. Así se percibe, por ejemplo, en un reciente trabajo donde Perus (2017) compara Los de abajo con "El Llano en llamas".

9 Mediante documentos históricos, Alberto Vital (2004, p. 127) identifica el sitio geográfico conocido como "La Cuesta de las Comadres", donde, informa, hubo un homicidio con arma punzocortante el $1^{\circ}$ de julio de 1908. Por cierto que el gran ironista Jorge Ibargüengoitia homenajeó a Rulfo denominando como la "Cañada de los Compadres" un sitio de su novela Los relámpagos de agosto (IBARGÜENGOITIA 2002, p. 85). 
pronto comencé a tener una fe muy grande en aquella aguja. Por eso, al pasar Remigio Torrico por mi lado, desensarté la aguja y sin esperar otra cosa se la hundí a él cerquita del ombligo. Se la hundí hasta donde le cupo. Y allí la dejé" (1953, p. 31). De este modo, el texto de Rulfo se asocia con el también jalisciense Campos Alatorre, de nuevo por el tono neutro mediante el cual se describen las acciones más terribles y sangrientas. Incluso el narrador anónimo presenta como un acto de misericordia la estocada final que, con esa larga aguja de arria, asesta a Remigio Torrico, luego de que la primera herida no provoca efectos mortales inmediatos:

Entonces vi que se le iba entristeciendo la mirada como si comenzara a sentirse enfermo. Hacía mucho que no me tocaba ver una mirada así de triste y me entró la lástima. Por eso aproveché para sacarle la aguja de arria del ombligo y metérsela más arribita, allí donde pensé que tendría el corazón. Y sí, allí lo tenía, porque nomás dio dos o tres respingos como un pollo descabezado y luego se quedó quieto (1953, p. 32).

Consumado su acto de fingida misericordia ${ }^{10}$, el narrador explica a Remigio, a quien supone ya muerto, cómo sucedió en realidad la muerte de Odilón, quien fue ajusticiado por unos enemigos suyos de Zapotlán a quienes él identifica como los Alcaraces. De este modo, el autor encuentra un artificio apropiado para transmitir la historia completa al lector real. En su estudio introductorio a una reciente edición de El Llano en llamas, Françoise Perus señala que, por lo general, los personajes de Rulfo no suelen presentarse como sujetos de acción, como en el realismo tradicional, sino que más bien recuerdan una situación pasada, en un incierto proceso rememorativo que no es igual en todos los textos; una de sus modalidades

...puede consistir en el soliloquio de algún personaje ensimismado que pareciera estar bregando solo con sus recuerdos, como es

10 Aunque no postulo una relación intertextual entre Rulfo y Ascasubi, sí deseo marcar cómo este cierre se parece a una de las estrofas de "La Refalosa", texto donde el cruel tono irónico es todavía más agudo cuando se describe la supuesta misericordia a favor del torturado: "Entre tanto, / nos clama por cuanto santo / tiene el cielo; / pero hay no más por consuelo / a su queja / abajito de la oreja, / con un puñal bien templao / y afilao, / que se llama el quita penas, / le atravesamos las venas / del pescuezo" (Ascasubi 1872, p. 132). 
el caso de la narración para sí del hermano de Tanilo Santos en "Talpa"; o bien el del relato del protagonista de "La Cuesta de las Comadres", cuya narración, a la par desafiante y esquiva, deja suponer la presencia de un interlocutor, aunque éste no llegue a nombrarse o identificarse nunca. En casos como éstos, los monólogos se encuentran internamente dialogizados, no sólo por cuanto su tono y su ritmo dan a entender la instancia particular desde la cual se enuncian, sino también por cuanto suelen bregar con la imagen de quienes se vinculan de una $\mathrm{u}$ otra manera a esta misma instancia (Perus 2016, p. 49).

A diferencia de lo que sucede en "La Cuesta de las Comadres", en "Hombre de la esquina rosada" sí se nombra e identifica al interlocutor: una entidad de ficción llamada "Borges", rasgo reiterado de su obra que, si no me equivoco, se inaugura en este texto. El personaje "Borges", oyente silencioso, funciona como aparente destinatario de la narración oral anónima, si bien esto no tiene tan sólo un estricto sentido individual, pues en un pasaje previo el narrador se dirige a un supuesto grupo de receptores: "Recordarán ustedes aquella ventana alargada por la que pasó en un brillo el puñal" (1935, p. 111). Como quiera que sea, hay un destinatario o unos destinatarios específicos, lo cual marca el acto voluntario de narrar para otro(s), con todas sus implicaciones.

Las coincidencias en el ejercicio del cuento entre Borges y Rulfo se basan también en su concepción del género. Como se sabe, el primero practicó con constancia diversas formas breves (cuento, reseña, ensayo breve, poema en prosa, etc.), las cuales hibridó con maestría. En el citado ensayo "El desafío de la creación", el segundo opina: "Para mí el cuento es realmente un género más importante que la novela, porque hay que concentrarse en unas cuantas páginas para decir muchas cosas, hay que sintetizar, hay que frenarse; en eso el cuentista se parece un poco al poeta, al buen poeta" (Rulfo 2007, p. 390); las reminiscencias de las ideas de Edgar Allan Poe son evidentes.

\section{Borges, PROloguista de Rulfo}

He planteado una relación intertextual entre Borges y Rulfo, a partir de las semejanzas entre dos textos narrativos y con base en el conocimiento comprobado que tenía el segundo de la 
obra inicial del primero. En sentido contrario la relación opera de manera directa, pues Borges alcanzó a incluir a Rulfo en su colección titulada Biblioteca Personal, planeada para llegar a cien volúmenes pero que, debido a su muerte, quedó trunca, con apenas sesenta y seis. Como es típico en el escritor argentino, se trata de una colección de obras ajenas (y sus respectivos prólogos) fundada en el mero hedonismo, más que en su valor estético, y en la influencia que hayan podido ejercer en sus respectivas historias literarias. Los únicos autores mexicanos que entraron en esa colección fueron los dos Juanes jaliscienses: Arreola y Rulfo (supongo que también habría pensado en incluir a Reyes). En 1986, Borges reunió una serie de relatos de Arreola bajo el título de Cuentos fantásticos, mediante el cual de entrada propone un contrato de lectura diferente, porque el mexicano nunca escribió un volumen que tuviera en su portada la palabra "fantástico" (incluso más bien su Confabulario es heredero del nombre Ficciones de Borges, pues ambos títulos marcan la condición de artificio verbal que funda su literatura); por cierto que, fiel a una reiterada costumbre suya que ahora se denomina autoplagio, el argentino tan sólo se limitó a reproducir el prólogo que un año antes, en 1985, había inaugurado una edición del Confabulario impresa por el Fondo de Cultura Económica.

Borges también prologó Pedro Páramo, poético título al cual Rulfo llegó luego de renunciar al nombre de Maurilio Gutiérrez con que inicialmente había bautizado a su personaje. Aunque el título de las obras clásicas suele convertirse para los lectores en algo esencial y necesario, casi una fatalidad, francamente el autor le habría hecho un flaco favor a su novela si la hubiera llamado Maurilio Gutiérrez. Tampoco parece poético (ni eufónico) el lugar primigenio donde ubicó su ficción: Tuxcacuesco, el cual incluso se me dificulta pronunciar, aunque soy mexicano; en cambio Comala, con su sucesión trimembre de consonantes y vocales fuertes, fluye eufónicamente (creo que García Márquez tuvo en mente esa estructura para denominar su mítico Macondo).

La lectura borgeana es una apropiación de Pedro Páramo para sus fines personales, pues en el arranque de su prólogo, una breve pero sustanciosa nota de menos de una página, Borges propone una clasificación de esa novela que de seguro sorprendería a quienes han acudido a ella para plantear el ámbito del realismo mágico: 
Desde el momento en que el narrador que busca a Pedro Páramo, su padre, se cruza con un desconocido que le declara que son hermanos y que toda la gente del pueblo se llama Páramo, el lector ya sabe que ha entrado en un texto fantástico, cuyas indefinidas ramificaciones no le es dado prever, pero cuya gravitación ya lo atrapa (Borges 1996, t. 4, p. 495).

Si bien las concepciones del género fantástico son múltiples y no siempre coincidentes, ninguna de ellas aceptaría que lo fantástico, en su sentido clásico, se produce en el arranque mismo del texto. En sus reflexiones, el propio Borges afirmó respecto del género:

...para convencer al lector [conviene] que haya un solo hecho fantástico en un cuento y que lo demás sea cotidiano; porque si todo es fantástico como sucede en tantos relatos de ficción científica, el lector no se resigna a imaginar tantas cosas fantásticas a un tiempo (Borges 1967, p. 6).

Es claro que en Pedro Páramo no hay un acontecimiento extraordinario único que contradiga las normas de un contrato de lectura mimético realista, sino una ficción narrativa donde el lector se enfrenta a una compleja serie de sucesos a-lógicos.

Así pues, habría que buscar otras razones para esa anómala clasificación. Quizá ésta se origine en la singular y compleja concepción borgeana de lo fantástico, que en general difiere de las reflexiones más canónicas. Conviene recordar que cuando Borges y Bioy Casares discutieron el probable título de la compilación de textos que en 1940, con el apoyo de Silvina Ocampo, se convirtió en la Antología de la literatura fantástica, el primero propuso el extraño título de Cuentos irreales, según confesó Bioy Casares en una entrevista (apud Sorrentino 1992, p. 78). Aunque comercialmente poco viable, sin duda el título señalaba lo que él quería decir: que esos textos discrepaban de cualquier poética afiliada al realismo. A mi juicio, en ese sentido debe entenderse la denominación global de Pedro Páramo como una novela fantástica.

Más allá de las siempre discutibles clasificaciones, que sólo deben ser un punto de partida, cabe recordar que Borges solía prestar poca (o casi nula) atención a la literatura hispanoamericana contemporánea, respecto de la cual incluso podía ser incisivamente irónico. Con Pedro Páramo, en cambio, no hay ironía 
alguna, sino elogios sintéticos e hiperbólicos. Así, después de enumerar algunas de las variadas y divergentes interpretaciones críticas suscitadas por la novela, concluye: "pero nadie ha logrado, hasta ahora, destejer el arco iris, para usar la extraña metáfora de John Keats" (Borges 1996, t. 4, p. 495). Y como remate, en apenas dos líneas -método que se parece a los dísticos con que solía cerrar sus sonetos-, expresa uno de sus más hiperbólicos juicios: "Pedro Páramo es una de las mejores novelas de las literaturas de lengua hispánica, y aun de la literatura" ( $i d$. .). Como él mismo reconocía, su estilo ensayístico era más conjetural que afirmativo; por ello debe destacarse que este elogio sobre la novela de Rulfo no está atenuado por las típicas modelizaciones borgeanas, es decir, precedido por adverbios o frases de duda, como "acaso" o "tal vez", que pululan en su estilo. En síntesis, si Rulfo acusa en la escritura de uno de sus cuentos la influencia directa de Borges, éste manifiesta de manera abierta su admiración irrestricta por Pedro Páramo ${ }^{11}$.

\section{A MODO DE CONCLUSIÓN}

Para concluir, deseo recordar el Premio Nacional de Lingüística y Literatura concedido en 1970 a Juan Rulfo, quien en el acto oficial de recepción pronunció el que quizá ha sido el discurso de agradecimiento más breve de nuestra historia cultural: apenas media página. Dijo entonces, atribuyendo a alguien más la idea, que los seres humanos no somos más que una "pura nada" ${ }^{12}$. Y por si esto no se entendía, reiteró: "No algo, ni cualquier cosa, sino una pura nada" (Rulfo 1970, p. 10). En efecto,

11 En una investigación futura se podrían examinar los probables nexos entre Pedro Páramo y la obra de Borges. Por ejemplo, en la línea sugerida en comunicación personal por Aníbal González, quien considera que el modelo de la enumeración dispar presente en el pasaje central de "El Aleph" pudo haber influido en la estructura de la novela de Rulfo. También cabría recordar que en la posdata de "El Aleph" se alude a una especie de Aleph sonoro, cuyo "atareado rumor" (Borges 1996, t. 1, p. 627) emana de una columna de la mezquita de Amr en El Cairo, sobre todo si se piensa en la importancia de los silencios y las voces en Pedro Páramo, así como en el hecho de que Los murmullos fue uno de los probables títulos que Rulfo imaginó para su novela.

${ }^{12}$ En el cuento de Borges, una idea semejante expresan dos mujeres frente al cadáver del Corralero: “-Para morir no se necesita más que estar vivo -dijo una del montón, y otra, pensativa: / -Tanta soberbia el hombre, y no sirve más que pa juntar moscas" (Borges 1935, p. 110). 
postulado un tiempo infinito, todo, absolutamente todo, será adjudicado a la nada y al olvido, desde Shakespeare y Cervantes hasta Borges y Rulfo. Pero antes de que el olvido invada todo, desafiemos al tiempo recordando a estos escritores de las dos orillas de Hispanoamérica, cuya espléndida literatura posibilita proclamar con esperanza que mientras haya fervientes lectores de su obra, ésta se preservará del olvido.

\section{REFERENCIAS}

Arreola, Juan José 1996. Memoria y olvido. Vida de Juan José Arreola (19201947), contada a Fernando del Paso, Conaculta, México.

Ascasubi, Hilario 1872. "La Refalosa", en Paulino Lucero o Los gauchos del Río de la Plata cantando y combatiendo contra los tiranos de las repúblicas argentina y oriental del Uruguay (1839 a 1851), Imprenta de Paul Dupont, Paris, pp. 130-134.

Bioy Casares, Adolfo 2006. Borges, Destino, Buenos Aires.

Borges, Jorge Luis 1930. Evaristo Carriego, M. Gleizer Ed., Buenos Aires.

Borges, Jorge Luis 1935. Historia universal de la infamia, Tor, Buenos Aires.

Borges, Jorge Luis 1950. Aspectos de la literatura gauchesca, Ed. Número, Montevideo.

Borges, Jorge Luis 1967. La literatura fantástica, Eds. Culturales Olivetti, Buenos Aires.

Borges, Jorge Luis 1996. Obras completas, Emecé, Buenos Aires, 4 ts.

Borges, Jorge Luis 1999. Un ensayo autobiográfico. Prol. y trad. Aníbal González, epílogo de María Kodama, Galaxia Gutenberg-Círculo de Lectores-Emecé, Madrid.

Brumme, Jenny 2008. "Introducción”, en La oralidad fingida: descripción y traducción. Teatro, cómic y medios audiovisuales. Ed. Jenny Brumme, Iberoamericana-Vervuert, Madrid, pp. 7-14.

Campos, Marco Antonio 2002. "De viva voz", en Arreola en voz alta. Ed. Efrén Rodríguez, Conaculta, México, pp. 163-175.

Campos Alatorre, Cipriano 1934. Los fusilados, Edición Sur, Oaxaca.

Cobián Rosales, Felipe 1986. "Dato fidedigno: Rulfo nació el 16 de mayo de 1917", en Los murmullos. Antología periodística en torno a la muerte de Juan Rulfo. Sel. de A. Sandoval, F. de J. Hernández y A. Trejo Villafuerte, Departamento del Distrito Federal, México, pp. 58-59.

Dorfman, Ariel 1970. Imaginación y violencia en América: ensayos sobre Borges, Asturias, Carpentier, García Márquez, Rulfo, Arguedas, Vargas Llosa, Editorial Universitaria, Santiago de Chile.

García Ponce, Juan 1964. “¿Quién es Borges?”, Revista Mexicana de Literatura, 5/6, pp. 23-42.

García Terrés, Jaime 1961. "Borges", en La feria de los días, Universidad Nacional Autónoma de México, México, p. 163.

Giusti, Roberto 1942. "Los premios nacionales de literatura”, Nosotros, $2^{\mathrm{a}}$ época, 76, pp. 115-116. 
IbARgüEngoitia, Jorge 2002. El atentado. Los relámpagos de agosto. Ed. crítica coordinada por Juan Villoro y Víctor Díaz Arciniega, ALLCA XX, Paris. (Archivos, 53).

Irby, James 1968. "Encuentro con Borges", en J. Irby, Napoleón Murat y Carlos Peralta, Encuentro con Borges, Galerna, Buenos Aires, pp. 7-53.

Ludmer, Josefina 1988. El género gauchesco. Un tratado sobre la patria, Sudamericana, Buenos Aires.

Olea Franco, Rafael 2006. "Un diálogo posible: Borges y Arreola”, en Los dones literarios de Borges, Iberoamericana-Vervuert, Madrid-Frankfurt/M., pp. 125-148.

Paz, OCtAvio 1986. "El arquero, la flecha y el blanco", Vuelta, 117, pp. $26-29$.

Perus, Françoise 2012. Juan Rulfo, el arte de narrar. Prol. José Pascual Buxó, RM-Universidad Nacional Autónoma de México, México.

Perus, Françoise 2016. "Introducción” a Juan Rulfo, El Llano en llamas. Ed. F. Perus, Cátedra, Madrid, pp. 11-76. (Letras Hispánicas, 768).

Perus, Françoise 2017. "Los de abajo de Mariano Azuela y «El Llano en llamas» de Juan Rulfo: alcances de un vínculo intertextual”, en Mariano Azuela y la literatura de la Revolución Mexicana. Ed. Rafael Olea Franco, El Colegio de México, México, pp. 245-273.

Piglia, Ricardo 2001. "Sobre Borges", en Crítica y ficción, Anagrama, Barcelona, pp. 73-86.

Real Academia Española 1989. Diccionario manual e ilustrado de la lengua española, $4^{\mathrm{a}}$ ed., Espasa Calpe, Madrid.

Roa Bastos, Augusto 1985. "La lección de Borges", Cuadernos Hispanoamericanos, 421/423, pp. 12-18.

Rulfo, Juan 1953. "El Llano en llamas" y otros cuentos, Fondo de Cultura Económica, México. (Letras Mexicanas, 11).

Rulfo, Juan 1970. "Discurso de agradecimiento", El Día, 26 de noviembre, p. 10.

Rulfo, JuAn 2000. Aire de las colinas. Cartas a Clara. Ed., pról. y notas de Alberto Vital, Debate, Madrid.

Rulfo, JuAn 2007. "El desafío de la creación”, en Toda la obra. Ed. crítica coordinada por Claude Fell, ALLCA-Fondo de Cultura Económica, México, pp. 388-390. (Archivos, 17).

Sommers, Joseph 2003. "Los muertos no tienen tiempo ni espacio (un diálogo con Juan Rulfo)", en La ficción de la memoria. Juan Rulfo ante la crítica. Sel. y pról. de Federico Campbell, Era-Universidad Nacional Autónoma de México, México, pp. 517-521. [Publicado originalmente en La Cultura en México, supl. de Siempre!, núm. 1051, 1973].

Sorrentino, Fernando 1992. Siete conversaciones con Adolfo Bioy Casares, Sudamericana, Buenos Aires.

Toro, Fernando DE 1999. "Borges and Rulfo: The paradigms of Modernity and Post-modernity", en El siglo de Borges. T. 1: Retrospectiva-presente-futuro. Eds. Alfonso de Toro, Fernando de Toro y René Ceballos, Iberoamericana-Vervuert, Madrid-Frankfurt/M., pp. 261-271. (Teoría y Crítica de la Cultura y Literatura, 19).

Ulla, Noemí 1990. Identidad rioplatense, 1930. La escritura coloquial (Borges, Arlt, Hernández, Onetti), Torres Agüero Ed., Buenos Aires. 
Valadés, Edmundo 1953. "El libro de Juan Rulfo quema las manos", México en la Cultura, supl. de Novedades, 29 de noviembre, p. 2.

Valenzuela, Alberto 1958. "Nuevos ingenios mexicanos: Octavio Paz, Juan Rulfo, Juan José Arreola, David N. Arce”, Ábside. Revista de Cultura Mexicana, 1, pp. 81-100.

Vital, Alberto 2004. Noticias sobre Juan Rulfo. 1784-2003, RM-Universidad Nacional Autónoma de México, México.

Williamson, Edwin 2006. Borges. Una vida. Trad. Elvio E. Gandolfo, Seix Barral, Buenos Aires. 